http://dx.doi.org/10.4314/ajtcam.v12i1.10

\title{
PEPTIDES EXTRACTED FROM ARTEMISIA HERBA ALBA HAVE ANTIMICROBIAL ACTIVITY AGAINST FOODBORNE PATHOGENIC GRAM-POSITIVE BACTERIA
}

\author{
Sinda Fedhila ${ }^{1 *}$, Wafa Ben Lazhar ${ }^{1}$, Taoufik Jeridi ${ }^{1}$, Vincent Sanchis ${ }^{2}$, Michel Gohar ${ }^{2}$, Didier Lereclus ${ }^{2}$, and Jeannette Ben Hamida ${ }^{1}$ \\ ${ }^{1}$ Higher Institute of Applied Biological Sciences of Tunis, Department of Biotechnology, Unity of Functional Proteomics and Food \\ Biopreservation, University Tunis El Manar, 1006 Tunis, Tunisia; ${ }^{2}$ INRA, UMR1319 Micalis, F-78280 Jouy-en-Josas, France. \\ * Corresponding author: Dr. Sinda Fedhila, Institut Supérieur des Sciences Biologiques Appliquées de Tunis, Département de Biotechnologie, \\ Unité Protéomique Fonctionnelle et Biopréservation Alimentaire, 9 avenue Zouheier Essafi, 1006 Tunis, Tunisie.
}

*E-mail: $\underline{\text { Sinda.Fedhila@ issbat.rnu.tn; }}$

\begin{abstract}
Background: Artemisia herba alba, classified into the family of Asteraceae, is an aromatic herb that is traditionally used as a purgative and antipyretic folk medicine by rural people of south Tunisia. This study reports the first identification of antimicrobial peptides from this medicinal plant that inhibited the growth of several food-borne pathogenic bacteria.

Materials and methods: The extraction and purification of peptidic agents from Artemisia herba alba, have been performed using precipitation by ammonium sulfate of a phosphate buffer crude extract obtained from the plant leaves, followed by reverse-phase HPLC on a C18 column. The mass of the peptides was estimated by SDS-PAGE electrophoresis, followed by a gel overlay assay and ultra-filtration through a $5 \mathrm{kDa}$ cut-off membrane. Fractions from every purification steps were sampled and assayed for activity towards different food-borne bacterial strains pathogenic and non pathogenic to humans.

Results: The phosphate buffer crude extract, as well as its ammonium sulfate precipitate, designated AS-P, inhibited the growth of Listeria monocytogenes, Staphylococcus aureus, Bacillus cereus sensu stricto and the new approved species Bacillus cytotoxicus. AS-P MICs (minimum inhibitory concentrations) ranged from 0.241 to $3.8 \mathrm{mg} / \mathrm{ml}$ proteins for L. monocytogenes and B. cereus sensu stricto (strains ATCC10987 and IP5832), respectively. The bioactive AS-P molecules were stable up to 10 minutes heating at $120^{\circ} \mathrm{C}$ and they resisted organic solvent effects. Antimicrobial activity of $A$. herba alba AS-P decreased to 40 and $60 \%$ after proteolytic treatment with trypsin and proteinase K, respectively, suggesting peptides being responsible for the A. herba alba AS-P activity. The mass of antibacterial A. herba alba peptides was estimated below $5 \mathrm{kDa}$. Two AS-P fractions, eluted at 40 and $37 \%$ acetonitrile, showed antibacterial activity when assayed against L. monocytogenes.

Conclusion: A. herba alba could make a new source of novel natural anti-infective agents that could be used in food bio-preservation as natural additives or in human infectious disease treatments against multi-drug resistant pathogens.
\end{abstract}

Key words: Ammonium sulfate precipitation, Artemisia herba alba, chromatography, Listeria monocytogenes, proteases, ultra-filtration

Abbreviations: AS-P: ammonium sulfate precipitate; MIC: minimum inhibitory concentration; PAMP: plant antimicrobial peptides ; PBC-E: phosphate buffer crude extract; RP-HPLC: reverse phase high-performance liquid chromatography ; SDS-PAGE: sodium dodecyl sulfate polyacrylamide gel electrophoresis; TSA: tryptic soy agar; TSB: tryptic soy broth

\section{Introduction}

Plant antimicrobial peptides (PAMP) are of great importance as components of barrier defense induced upon infection in a wide variety of plants (Garcia-Olmedo et al., 1998). A large proportion of them share common characteristics. They are generally small $(<10 \mathrm{kDa})$ and highly basic with positively charged residues and a high cystein content leading to the formation of disulphide bonds providing the peptides with an amphiphilic compact structure (Lay and Anderson, 2005). Based on primary sequence similarity and activity towards bacteria, these peptides are classified into different groups including Defensins, Lipid transfer proteins, Knottins, Hevein- and Vicilin-like peptides, Snakins and Cyclotides. PAMP have been isolated from roots, seeds, flowers, stems, and leaves and have demonstrated activities towards phytopathogens, as well as against bacteria pathogenic to humans (Hammami et al., 2009a).

Over the years, PAMP have become an interesting tool for the development of new techniques in the control of crop losses. Indeed, overexpressing endogenous or exogenous PAMP endow transgenic plants with partial or total resistance against different phytopathogens. For instance, the generation of transgenic tomato plants constitutively expressing the chili defensin gene (cdefl) resulted in enhanced resistance against Phytophthora infestans and Fusarium sp. (Zainal et al., 2009). Expression of Dahlia defensin, Dm-AMP1, in rice, directly inhibits the pathogens, Magnaporthe oryzae and Rhizoctonia solani (Jha et al., 2009). Transgenic sweet potato expressing thionin from barley has been shown to give resistance to black rot disease caused by Ceratocystis fimbriata in leaves and storage roots (Muramoto et al., 2012).

Several studies have also demonstrated the in vitro antibacterial effects of PAMP against various bacterial species pathogenic and non pathogenic to humans, such as Staphylococcus aureus, Streptococcus faecalis, Micrococcus luteus, Listeria monocytogenes, Listeria ivanovii, Escherichia coli, Pseudomonas aeruginosa, Proteus vulgaris and Klebsiella oxytoca, at micromolar concentrations (Barbosa Pellegrini et al., 2011; Stotz et al., 2009; Lopez-Solanilla et al., 2003; Hammami et al., 2009c). However, to date, only their cognates from bacteria and mammals as well as their synthetic mimics enjoy practical applications in human infectious disease treatments as novel antibiotics against multi-drug resistant pathogens; or in biopreservation as novel food additives (Mills et al., 2011; Som et al., 2008; Yeung et al., 2011).

In the present study, we report the extraction of proteinaceous antibacterial molecules from Artemisia herba alba leaves, their partial chemical characterization, and the assessment of their antibacterial effects against several foodborne bacterial species pathogenic to humans. $A$. herba alba (Asteraceae) is known as "desert wormwood" or "Chih", as it is commonly named in North Africa. It is a popular medicinal and aromatic herb growing in arid and semi-arid climates characteristics of the steppes and deserts of South Tunisia. This plant is particularly known for its purgative and anti-pyretic properties (Idris et al., 1982). Phytochemical investigations have extracted from this genus various aromatic substances such as terpenoïds, flavonoïds, coumarins, acetylenes, caffeoylquinic acids and sterols. These molecules have been shown to have multiple beneficial bioactivities: anti-malarial, anti-viral, anti-tumor, anti-hemorrhagic, anti-coagulant, anti-anginal, anti-oxidant, antidiabetic activities and strong antibacterial activities against several human pathogens (Ahmed et al., 1990; Saleh et al., 1985; Messaoudene et al., 2011; Neerman, 2003).

This study is the first of the kind purifying PAMP from A. herba alba, with the aim to explore their potential for applied biotechnology as natural food-preservative candidates or as novel beneficial therapeutics in overcoming infectious diseases, derived from a new source, especially plant source. 


\section{Materials and Methods \\ Plant material}

A. herba alba was collected from different localities in the region of Tataouine (south Tunisia) during June 2009. The plant was identified by Dr. Zeyneb Ghrabi, Department of Agronomy and Plant Biotechnology, University of Carthage, National Agronomy Institute of Tunisia (INAT), where the voucher specimen (\#D1472) is deposited.

\section{Bacterial strains and growth conditions}

Bacteria used throughout this study are Listeria monocytogenes MACa1, Escherichia coli DH5a, Staphylococcus aureus ATCC25923, Pseudomonas aeruginosa PAO1, Salmonella arizona ATCC25922 strains (PF\&BA laboratory stock), Bacillus cereus sensu stricto reference strains ATCC14579, ATCC10987, IP5832 and the B. cereus ATCC14579 $d$ dlt mutant strain (MICALS-INRA laboratory stock) as well as the new identified thermotolerant Bacillus cytotoxicus NVH391/98 pathogenic species of the B. cereus group (Guinebretière et al., 2012). All strains were cultured in Tryptic Soy Broth (TSB; Difco Laboratories, Sparks, MD) supplemented with $0.6 \%$ (w/v) yeast extract with vigorous shaking (175 rpm) at $37^{\circ} \mathrm{C}$.

\section{Preparation of crude extracts and ammonium sulfate precipitates}

Crude extracts were prepared as follows. One gram of A. herba alba dry leaves was ground in a mortar, and the resulting fine powder was incubated with $10 \mathrm{ml}$ of cold organic solution (ethanol $80 \%$ or methanol $80 \%$ ) or aqueous extraction buffer (Tris- $\mathrm{HCl}$ buffer $(0.5 \mathrm{M}, \mathrm{pH} 6)$ or phosphate buffer (sodium - phosphate $0.04 \mathrm{M}, \mathrm{pH} 7$ ) or urea buffer $(10 \%, \mathrm{pH} 7)$ ). The different extracts were centrifuged at $6,000 \mathrm{rpm}$ for 30 minutes and the supernatants were adjusted to $\mathrm{pH} 7$ with $\mathrm{NaOH}$ and passed through a $0.44 \mu \mathrm{m}$ filter (Millipore, MA, USA). For subsequent assays, benzamidine was added to aqueous extracts at a final concentration of $1 \mathrm{mM}$. Ammonium sulfate precipitates, designated AS-P, were prepared as follows. Solid ammonium sulfate was slowly added to $10 \mathrm{ml}$ of phosphate buffer crude extract, designated PBC-E, under continuous stirring, up to $80 \%$ saturation at $4^{\circ} \mathrm{C}$. The precipitated proteins were recovered by centrifugation $\left(6,000 \mathrm{rpm}\right.$ for 30 minutes, $\left.4^{\circ} \mathrm{C}\right)$ and stored at $4^{\circ} \mathrm{C}$ until use. For subsequent assays, the pellet was resuspended in a two milliliter amount of phosphate extraction buffer and filtered again through a $0.44 \mu \mathrm{m}$ filter (Millipore, MA, USA). The protein content of the AS-P was determined with the method of Bradford (1976) simultaneously with bovine serum albumin as a standard.

\section{Assays for in vitro susceptibility to antimicrobial activity}

Susceptibility to antimicrobial activity was evaluated using the agar-well diffusion method as described previously (Perez et al., 1990). $200 \mu \mathrm{l}$ of an overnight culture was gently mixed with $20 \mathrm{ml}$ of sterile TSA (TSB medium containing $0.7 \%$ agar) at $45^{\circ} \mathrm{C}$. The bacteria-seeded medium was poured into a sterile Petri dish and allowed to gel for 30 minutes at room temperature then stored at $4^{\circ} \mathrm{C}$. Wells were punched in the agar plate using the wide end of a sterile Pasteur pipette $(5 \mathrm{~mm}$ diameter). $50 \mu \mathrm{l}$ of the different samples were dispensed into each well. Plates were kept at $4^{\circ} \mathrm{C}$ for 30 minutes to allow the liquid to diffuse into the seeded agar before overnight incubation at $37^{\circ} \mathrm{C}$. All assays were carried out in triplicate on 3 different occasions. Positive and negative controls consisted on polymixin B sulfate $(2 \mu \mathrm{g} / \mathrm{ml})$ (Sigma) and phosphate buffer, respectively. Inhibition was scored positive if the width of the clear zone around the well was $\geq 6 \mathrm{~mm}$. For MIC (minimum inhibitory concentration) evaluation, sterile microtiter plates with 96 wells were used. Bacterial strains were cultured to late exponential growth phase $\left(\mathrm{OD}_{600 \mathrm{~nm}} \approx 1.2\right)$ in TSB at $37^{\circ} \mathrm{C} .20 \mu \mathrm{l}$ of the culture, diluted to $1: 1,000$ (corresponding to approximately $10^{6} \mathrm{CFU} / \mathrm{ml}$ ), were dispensed into individual wells containing various concentrations of AS-P, resulting from twofold serial dilutions of an initial $10.8 \mathrm{mg} / \mathrm{ml} \mathrm{protein}$ set. Controls consisted on $150 \mu \mathrm{l} \mathrm{TSB}+20 \mu \mathrm{l}$ of the bacterial strain (negative control), $100 \mu \mathrm{l} \mathrm{TSB}+50 \mu 1$ polymyxin B sulfate $(2 \mu \mathrm{g} / \mathrm{ml})+20 \mu \mathrm{l}$ of the bacterial strain (positive control) and TSB medium alone (indicator of contamination). Growth was scored after 24 hours of incubation at $37^{\circ} \mathrm{C}$. Growth data were recorded by reading $\mathrm{A}_{630 \mathrm{~nm}}$ using a microplate reader (Biotech, ELx808). The MIC value was considered to be the lowest AS-P concentration that inhibited cell growth.

\section{SDS-PAGE and gel overlay assay}

$10 \mu \mathrm{l}$ of the different samples were subjected to 12\% SDS-PAGE (Laemmli, 1970). The gel was Coomassie Blue R-250 stained. The gel-overlay test was performed as previously described (Cherif et al., 2001): the gel was soaked in a fixing solution (25\% isopropanol, $10 \%$ acetic acid) for 30 minutes, then washed twice with sterile double-distilled water for 1 hour and overlaid on a Petri dish containing $5 \mathrm{ml}$ of $L$. monocytogenes-seeded TSA medium (4\%). The Petri dish was incubated at $37^{\circ} \mathrm{C}$ for 24 hours and examined for the presence of a growth inhibition zone. In the negative control, the overlay-assay was performed with the phosphate buffer subjected to SDS-PAGE.

\section{Characterization of the active compounds}

The thermostability of the antimicrobial activities was determined by heating active samples at $90^{\circ} \mathrm{C}, 100^{\circ} \mathrm{C}$ and $120^{\circ} \mathrm{C}$ for 20 minutes in water bath. The effect of proteolytic treatments on antimicrobial activity was assessed by using trypsin (10 mg/ml, Sigma Chemicals), and proteinase K (10 mg/ml, Sigma Chemicals) as follows. $100 \mu \mathrm{l}$ of selected samples were heated at $95^{\circ} \mathrm{C}$ for 10 minutes and centrifuged at 10,000 rpm for 10 minutes in order to remove endogenous proteases and high molecular weight proteins. The supernatants were recovered, incubated individually in Tris- $\mathrm{HCl}\left(50 \mathrm{mM}, \mathrm{pH}\right.$ 8) with $10 \mu \mathrm{l}$ of each enzyme for 60 minutes at $37^{\circ} \mathrm{C}$. Two negative control experiments were used: (i) sample incubated with heat-inactivated proteases (10 minutes in hot boiling water); (ii) proteases alone incubated in phosphate extraction buffer. The percentage of activity was calculated in relation to the negative control incubated with heat-inactivated proteases. Stability in organic solvents was evaluated by mixing active samples with an equal volume of methanol $100 \%$, isopropanol $99 \%$, chloroform $100 \%$, hexane $100 \%$ and acetonitrile $100 \%$, separately. After incubation at room temperature for two hours, the solvents were evaporated and the dried samples were redissolved in $100 \mu \mathrm{l}$ phosphate extraction buffer. All treated samples were tested for residual antibacterial activity by the agar-well diffusion method. All tests were repeated at least 3 times. 
http://dx.doi.org/10.4314/ajtcam.v12i1.10

\section{Ultrafiltration}

One ml of the AS-P sample was filtered through $0.22 \mu \mathrm{m}$ filter (Millipore, MA, USA) and then dropped onto 10, 5 and $1 \mathrm{kDa}$ cut-off membranes (Amicon Ultracell, Millipore). The filtrates were collected separately after centrifugation at 8,000 rpm for four hours.

\section{RP-HPLC analysis}

The AS-P was fractionated in reverse phase HPLC on a C18 column (Lichrospher RP18 $5 \mu \mathrm{m}$, Supelco Inc. $250 \times 4.6 \mathrm{~mm}$ ). Fractions were eluted in $0.1 \%$ trifluoroacetic acid at flow rate of $1 \mathrm{ml} / \mathrm{min}$ using a linear acetonitrile gradient $(0-80 \%$, v/v, in $60 \mathrm{minutes})$. Elution was monitored at $214 \mathrm{~nm}$ and fractions were manually peak-based collected. Acetonitrile volume in the eluted fractions was adjusted to $200 \mu \mathrm{l}$ by heat drying at $37^{\circ} \mathrm{C}$. Fractions were assayed for the antibacterial activity by agar-well diffusion method. The RP-HPLC retention time and the percentage of acetonitrile of each fraction were determined when the peak was at its maximum height.

\section{Results}

\section{Antibacterial activity of $A$. herba alba crude extracts and ammonium sulfate precipitates}

We performed three aqueous (in phosphate, Tris- $\mathrm{HCl}$ and urea buffers) and two organic (acetonic and methanolic) crude extracts from leaves of $A$. herba alba collected from Tatouine, an arid region of south Tunisia. These buffers and solutions have been successfully used for the extraction of plant antimicrobial compounds of organic and proteinaceous nature (Odani et al., 1987; Hammami et al., 2009c). The antibacterial activity of these extracts was examined towards different foodborne bacterial species, pathogenic and non pathogenic to humans: $E$. coli, $L$. monocytogenes, $S$. aureus, $S$. arizona, four B. cereus strains, and B. cytotoxicus by using the agar-well diffusion method and by determining their minimum inhibitory concentrations (MICs).

Table 1 summarizes all the results obtained with the different extraction solutions against the bacterial species tested. A selective antibacterial activity directed against $\mathrm{Gram}^{+}$bacteria with clear zones of growth inhibition ranging from 10 to $18 \mathrm{~mm}$, was obtained with the aqueous extracts, whereas controls had no effects (data not shown). In contrast to the aqueous extracts, none of the two organic extracts used exhibited activity against the bacteria (data not shown). An example of the inhibitory activity of some extracts, against $B$. cytotoxicus, obtained by the agar diffusion test is presented in figure 1. These results suggest that the extracted active biomolecules have hydrophilic and polar properties. In order to check whether these antibacterial activities are due to plant agents of proteinaceous nature, we further tested the effect of $A$. herba alba phosphate buffer crude extract, designated PBC-E, submitted to precipitation with ammonium sulfate at a concentration (80\%) known to precipitate most proteins, including low molecular weight proteins such as peptides. Like all the crude aqueous extracts tested, the ammonium sulfate precipitate, dissolved in phosphate buffer and designated AS-P, displayed antibacterial activity against only Gram ${ }^{+}$bacteria. This activity was increased comparatively to the crude extract, probably due to a greater AS-P average protein concentration $(2.98 \mathrm{mg} / \mathrm{ml}$ for the PBC-E versus $11.2 \mathrm{mg} / \mathrm{ml}$ for the AS-P). MIC data obtained among bacteria are correlated with the agar-well diffusion results (Table 1). L. monocytogenes, S. aureus and $B$. cereus $\Delta d l t$ mutant strain displayed the lowest MIC values $(0.241 \mathrm{mg} / \mathrm{ml}$ and $0.483 \mathrm{mg} / \mathrm{ml}$, respectively), thus representing the most susceptible bacteria of the group tested.

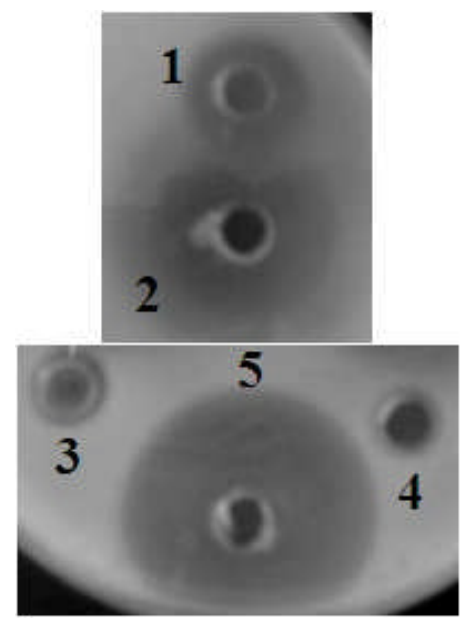

Figure 1: Antibacterial activity of the A. herba alba phosphate buffer crude extract PBC-E and ammonium sulfate precipitate, AS-P, against $B$. cytotoxicus clinical NVH391/98 isolate determined by agar-well diffusion test. 1, 2, 3, 4, 5: $50 \mu$ of $A$. herba alba PBC-E (2.98 mg/ml), A. herba alba AS-P (11.2 mg/ml), AS-P supernatant, negative control (phosphate buffer), positive control (polymixin B sulfate, $2 \mu \mathrm{g} / \mathrm{ml}$ ), respectively.

\section{Partial chemical characterization of the $A$. herba alba AS-P antimicrobial compounds}

The chemical nature of the AS-P active compounds was evaluated by testing their antibacterial activity by agar-well diffusion method, after submitting them to heat $\left(20\right.$ minutes at $90^{\circ} \mathrm{C}, 100^{\circ} \mathrm{C}$ and $120^{\circ} \mathrm{C}$ ), different solvents (Methanol $100 \%$, Ethanol $100 \%$, Acetone $100 \%$, Isopropanol 99\% and Acetonitrile 100\%) and proteases (Proteinase K and Trypsin at $10 \mathrm{mg} / \mathrm{ml}$ ). A. herba alba AS-P retained 90 to $100 \%$ activity against the whole $\mathrm{Gram}^{+}$bacteria tested after submitting to all heat and solvent treatments (data not shown). However, the two proteases decreased the susceptibility of the bacteria to treated AS-P (Fig. 2). Indeed, Proteinase K and Trypsin resulted in loss of average $40 \%$ and $60 \%$ of activity. The control consisting on protease alone did not display any antibacterial activity (Fig. 2). 
Fedhila et al., Afr J Tradit Complement Altern Med. (2015) 12(1):68-75

http://dx.doi.org/10.4314/ajtcam.v12i1.10

Table 1: Antibacterial activity of $A$. herba alba crude extracts and ammonium sulfate precipitates against the different bacterial species tested

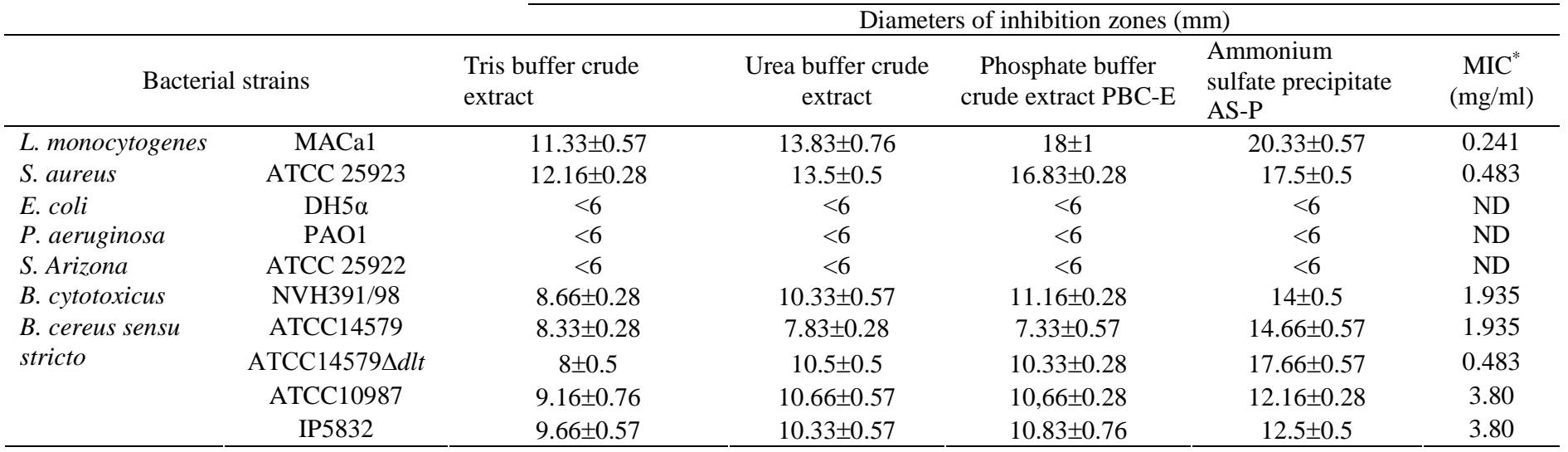

All assays were carried out in triplicate and values are expressed as mean \pm SEM

* MIC values of the AS-P

ND. Non determined

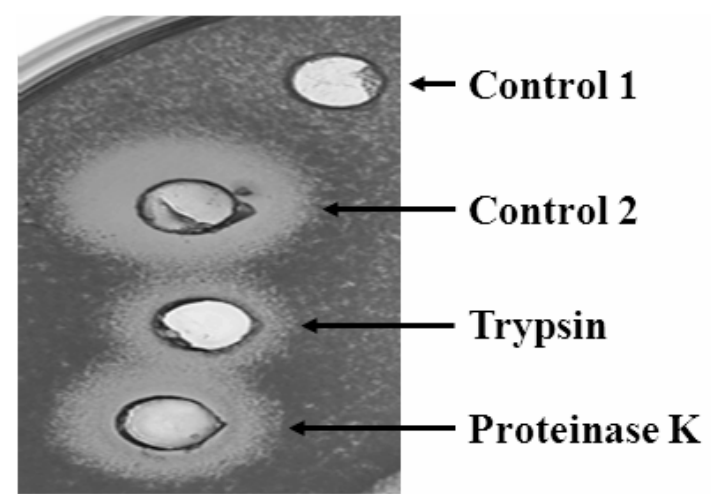

Figure 2: Agar-well diffusion test illustrating the effects of proteases on antimicrobial activity of $A$. herba alba AS-P against $B$. cytotoxicus clinical NVH391/98 isolate. $100 \mu \mathrm{l}$ of AS-P sample $(11.2 \mathrm{mg} / \mathrm{ml})$ were incubated with $10 \mu \mathrm{l}$ trypsin $(10 \mathrm{mg} / \mathrm{ml})$ and proteinase $\mathrm{K}(10 \mathrm{mg} / \mathrm{ml})$, separately in appropriate buffers for 60 minutes at $37^{\circ} \mathrm{C}$. Control 1: phosphate buffer containing protease alone. Control 2: AS-P mixed with proteases preincubated for 10 minutes in hot boiling water.

\section{Detection and estimation of molecular mass}

A. herba alba AS-P was subjected to SDS-polyacrylamide gel electrophoresis followed by a gel overlay assay in order to separate the active AS-P components and to identify the protein band responsible for the antibacterial activity. The Coomassie blue stained acrylamide gel showed a smear of proteins weighing from 200 to less than $10 \mathrm{kDa}$ (Fig. 3A). After electrophoresis, the gel was overlaid with L. monocytogenesseeded agar. A. herba alba AS-P antibacterial activity was detected as a clear zone of inhibition corresponding to proteins with molecular mass below to $6.5 \mathrm{kDa}$ (Fig. 3B). No inhibition zone was detected with the negative control in which phosphate buffer alone was submitted to SDSPAGE (data not shown).

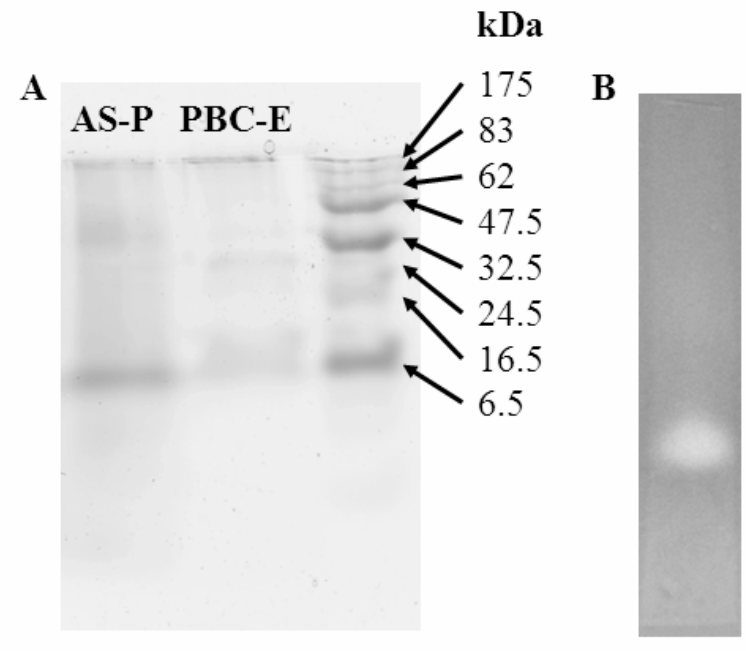

Figure 3: Detection and estimation of A. herba alba AS-P bioactive peptides molecular mass.

(A) SDS-PAGE profiles of A. herba alba PBC-E and AS-P. $10 \mu \mathrm{l}$ of PBC-E sample $(2.98 \mathrm{mg} / \mathrm{ml})$ and $10 \mu \mathrm{lof}$ AS-P sample (11.2 mg/ml) were subjected to SDS-PAGE 12\%. Molecular marker band sizes are shown. Molecular weight markers are shown on the right (Biorad, Broad range standards). 
http://dx.doi.org/10.4314/ajtcam.v12i1.10

(B) Gel overlay assay. The electrophoresis gel was overlaid with TSA soft agar (4\%) inoculated with L. monocytogenes and incubated for 24 hours at $37^{\circ} \mathrm{C}$. A clear zone (lack of bacterial colonies) on the bacterial underlayer, corresponding to bands below $6.5 \mathrm{kDa}$ on the SDS-PAGE gel, is shown.

Our results show that the antibacterial compound is small and not denaturated by SDS or DTT. To confirm that this antibacterial activity was due to small peptides, $A$. herba alba AS-P extract was ultrafiltrated through a 10,5 and $1 \mathrm{kDa}$ cut-off membranes and the ultrafiltrates were tested separately against L. monocytogenes by the agar well diffusion method. Clear halos of inhibition were detected only with the ultrafiltrates obtained with the 10 and $5 \mathrm{kDa}$ cut-off membranes (Fig. $4 \mathrm{~b}$ and Fig. 4c, respectively).

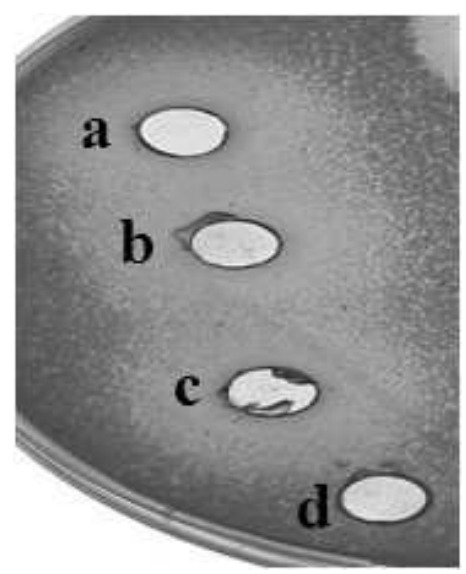

Figure 4: Antibacterial activity of the A. herba alba AS-P submitted to ultrafiltration. A. herba alba AS-P was ultrafiltrated through a 10 (b), a 5 (c) and a $1 \mathrm{kDa}(\mathbf{d})$ cut-off membranes and the resulting filtrates were assayed against $L$. monocytogenes by agar-well diffusion method. Inhibition zones formed are shown. (a): control consisting on non filtered A. herba alba AS-P.

\section{RP-HPLC Purification}

A. herba alba AS-P was subjected to reverse-phase high-performance liquid chromatography (RP-HPLC). Only two fractions, designated A1 and A2 (Fig. 5A), which eluted at $214 \mathrm{~nm}$ with 37.35 and $40 \%(\mathrm{v} / \mathrm{v})$ acetonitrile, respectively, exhibited efficient antibacterial activity against L. monocytogenes growth (Fig. 5B). A1 and A2 protein contents, estimated by UV absorption at $595 \mathrm{~nm}$ according to Bradford (1976), were 2.83 and $1 \mu \mathrm{g} / \mathrm{ml}$, respectively.

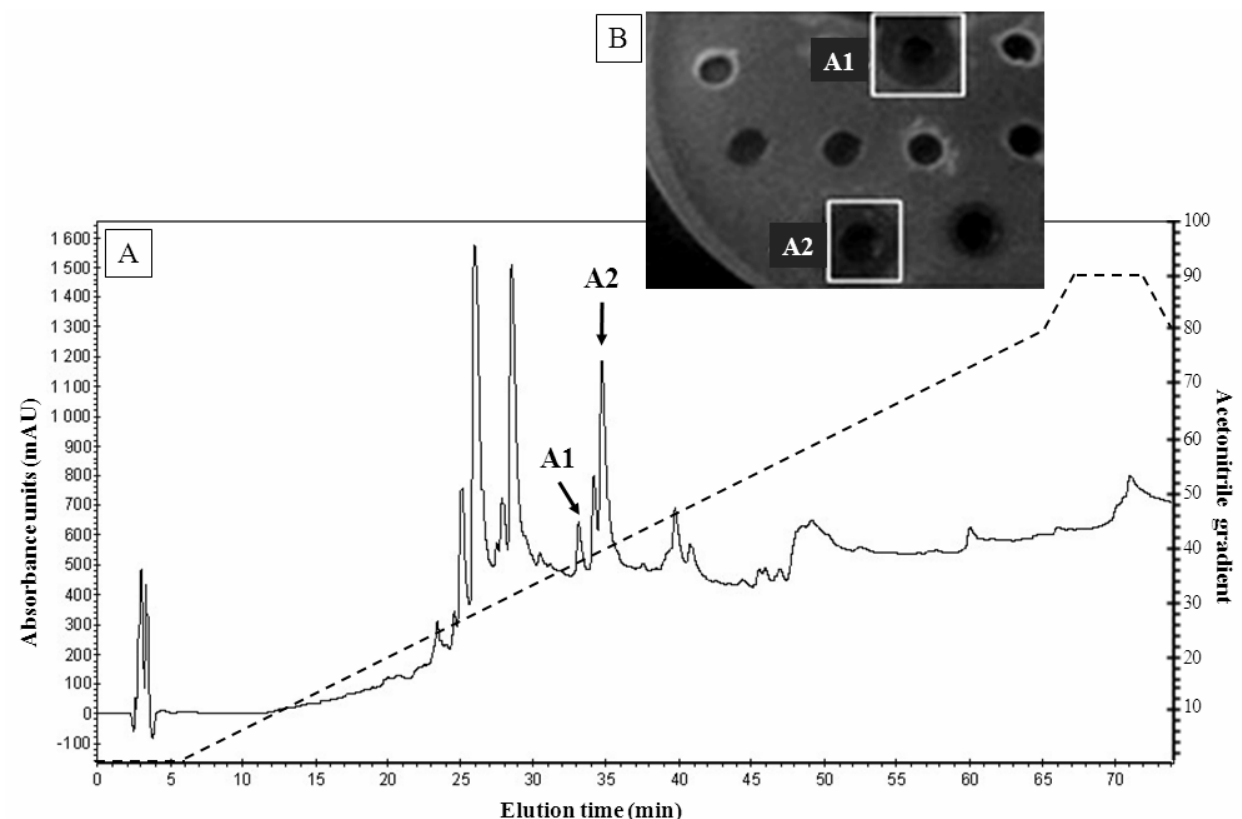

Figure 5: Antibacterial activity of the A. herba alba AS-P fractioned by RP-HPLC. (A) Reverse-phase HPLC was performed to separate molecules of the A. herba alba AS-P sample. AS-P sample was chromatographed on a C18 column. The different fractions were eluted in $0.1 \%$ trifluoroacetic acid at flow rate of $1 \mathrm{ml} / \mathrm{min}$ for 60 minutes using a linear acetonitrile gradient $(0-80 \%, \mathrm{v} / \mathrm{v}$, broken lane). A1 and A2 fractions were manually collected with 37.35 and $40 \%$ (v/v) acetonitrile, under peaks with a 33 and a 35 minutes retention time, respectively.

(B) Antibacterial activity of the eluted fractions assayed against $L$. monocytogenes by agar-well diffusion method. Clear inhibition zones are shown. 


\section{Discussion}

In this study we have purified antimicrobial peptides from A. herba alba, a wild-medicinal plant from arid regions of Tunisia. These peptides were selectively active against four major $\mathrm{Gram}^{+}$bacterial species regarded as foodborne and opportunistic pathogens to humans: $L$. monocytogenes, $S$. aureus, B. cereus sensu lato, and B. cytotoxicus. L. monocytogenes, the most susceptible bacteria to the purified A. herba alba peptides, is the causative agent of Listeriosis, a severe animal and human foodborne disease, especially characterized by central nervous system infections and foetal or neonatal infections associated with a high mortality rate despite early antibiotic treatments (Vazquez-Boland et al., 2001). S. aureus infections are a growing public health problem due to emergence of antibiotic-resistant bacterial strains (De Leo and Chambers, 2009). S. aureus can reside for years on the skin and nasal mucosa in humans without causing disease (Kluytmans et al., 1997; Wertheim et al., 2005). When these barriers are breached, systemic infection with diverse manifestations can occur, including pneumonia, meningitis, osteomyelitis, endocarditis and toxic shock syndrome. S. aureus ATCC 25923 is a reference strain of S. aureus isolated in the USA in Seattle in 1945 and harbouring PVL toxin which is regarded as a marker of virulence in S. aureus (Holmes et al., 2005). B. cereus is an opportunistic pathogen causing foodborne gastroenteritis resulting from the production of an emetic toxin, of hemolysins or of enterotoxins, such as Hbl or Nhe (Stenfors Arnesen et al., 2008). In some rare circumstances, B. cereus has been found associated with more severe infections, for example bacteremia, pneumonia and endophthalmitis (Hilliard et al., 2003; Miller et al., 1997; Callegan et al., 2003). B. cytotoxicus, a novel foodborne pathogen, of a previously unknown species of the $B$. cereus group, was responsible for a severe case of diarrhoeal food poisoning causing three deaths in France (Lund et al., 2000; Guinebretière et al., 2012; Fagerlund et al., 2007; Auger et al.,, 2008). Selectivity among PAMP has been reported by many studies, such as for the knottins (Cammue et al., 1992; Liu et al., 2000) and for the Hevein-like peptides (Martins et al., 1996; Van Den Bergh et al., 2002) which are specifically active against $\mathrm{Gram}^{+}$bacteria. Since most antimicrobial peptides interact with the bacterial membrane as initial step of the process leading to death, the variation in the spectrum of activity is likely to be due to structural differences between $\mathrm{Gram}^{+}$and $^{-\mathrm{Gram}^{-}}$ bacterial membranes (Hancock, 2001; Tossi et al., 2000).

The peptidic nature of the crude extract bioactivity was demonstrated by protease susceptibility of its ammonium sulfate precipitate, AS$\mathrm{P}$. Indeed, the AS-P was resistant to heat, to organic solvents and displayed decreased antibacterial activity after submission to proteinase K and trypsin. Another major finding emerging from this study which is consistent with peptides being responsible for the extract's activity is that the mutant strain B. cereus ATCC14579 $\Delta d l t$ was more susceptible to A. herba alba AS-P than the parental strain. The dlt operon of gram-positive bacteria encodes proteins required for the incorporation of D-alanine esters into both lipoteichoic and cell wall-associated teichoic acids and thereby decreases the density of negative charge in the cell wall. This repulses positively charged molecules and confers resistance to animal and human cationic AMP in Gram ${ }^{+}$pathogenic bacteria (Collins et al., 2002; Abachin et al., 2002; Kovacs et al., 2006). A recent study has shown that inactivation of the dlt operon decreases $B$. cereus resistance to antimicrobial peptides and drastically reduces virulence of the bacteria in insect larvae (Abi-Khatar et al., 2009).

As indicated by activity detection after SDS-PAGE and ultrafiltration, the apparent molecular mass of the AS-P peptides ranged between 5 and $1 \mathrm{kDa}$. It is known that PAMP have generally a relatively small size: ranging from $0.876 \mathrm{kDa}$ to $8.864 \mathrm{kDa}$ for Cn-AMP1 and Vicilin-like 2c-3 peptides from Cocos nucifera and Macadamia integrifolia, respectively (Mandal et al., 2009; Marcus et al., 1999). Peptides weighing less than $2.5 \mathrm{kDa}$ were purified from the seeds of a south Tunisia originated plant, Oudneya africana, and found to be active against $L$. monocytogenes, E. coli, Bacillus subtilis, Enterococcus hirae, P. aeruginosa, S. aureus and Candida albicans (Hammami et al., 2009b). In the final chromatography step, the A. herba alba AS-P was fractioned by reverse phase HPLC and all fractions were tested for antibacterial activity against L. monocytogenes. Only two fractions absorbing UV at $214 \mathrm{~nm}$ and eluted at acetonitrile concentrations of $37 \%$ and $40 \%$ were active. We can speculate that the growth inhibition zones obtained with the small sized peptides by direct detection of the AS-P activity on SDS-PAGE could be attributed to these fractions. Experiments are in progress to isolate and sequence these peptides.

\section{Conclusions}

The present study is a contribution to investigating the potential of plants, especially the medicinal nondomesticated ones originated from arid regions of south Tunisia, as a new source of novel natural additives for food biopreservation or novel anti-infective agents for human infectious disease treatments against multi-drug resistant pathogens. Peptides purified from $A$. herba alba could have such applications since they exhibited antimicrobial activity against pathogenic bacteria. Antimicrobial assays in food would allow us to determine if these purified peptides could make newer tools in food systems in terms of safety, quality, and improvement of human health.

\section{Acknowledgements}

This work was supported by the Agence Universitaire de la Francophonie (project no. 6313PS808 [Etude de la résistance de bactéries pathogènes aux peptides antimicrobiens et recherche de nouveaux peptides d'origine végétale]).

\section{References}

1. Abachin, E., Poyart, C., Pellegrini, E., Milohanic, E., Fiedler, F., Berche, P. and Trieu-Cuot. P. (2002). Formation of D-alanyl-lipoteichoic acid is required for adhesion and virulence of Listeria monocytogenes. Mol. Microbiol. 43: 1-14.

2. Abi Khattar, Z., Rejasse, A., Destoumieux-Garzón, D., Escoubas, J.M., Sanchis, V., Lereclus, D., Givaudan, A., Kallassy, M., NielsenLeroux, C. and Gaudriault, S. (2009). The dlt operon of Bacillus cereus is required for resistance to cationic antimicrobial peptides and for virulence in insects. J. Bacteriol. 191(22): 7063-73.

3. Ahmed, A.A., Abou El-Ela, M., Jakupovic, J., Seif El-Din, A.A., and Sabri, N. (1990). Eudesmanolides and other constituents from Atemisia herba alba. Phytochem. 29: 3661-3663.

4. Auger, S., Galleron, N., Bidnenko, E., Ehrlich, S.D., Lapidus, A. and Sorokin, A. (2008). The genetically remote pathogenic strain NVH39198 of the Bacillus cereus group is representative of a cluster of thermophilic strains. Appl. Environ. Microbiol. 74: 1276-1280.

5. Barbosa Pelegrini, P., Perseghini del Sarto, R., Nascimento Silva, O., Luiz Franco, O. and Grossi-de-Sa1, M.F. (2011). Antibacterial peptides from plants: what they are and how they probably work. Biochem. Res. Int. 250349. 
http://dx.doi.org/10.4314/ajtcam.v12i1.10

6. Bradford, M.M. (1976). A rapid and sensitive method for the quantitation of microgram quantities of protein utilizing the principle of protein-dye binding. Anal. Biochem. 72: 248-54

7. Callegan, M.C., Kane, S.T., Cochran, D.C., Gilmore, M.S., Gominet, M. and Lereclus, D. (2003). Relationship of PlcR-regulated factors to Bacillus endophthalmitis virulence. Infect. Immun. 71: 3116-3124.

8. Cammue, B.P.A., De Bolle, M.F.C., Terras, F.R.G., Proost, P., Van Damme, J., Rees, S.B., Vanderleyden, J. and Broekaert, W.F. (1992). Isolation and characterization of a novel class of plant antimicrobial peptides from Mirabilis jalapa L. seeds. J. Biol. Chem. 267(4): 22282233.

9. Cherif, A., Ouzari, H., Daffonchio, D., Cherif, H., Ben Slama, K., Hassen, A., Jaoua, S. and Boudabous, A. (2001). Thuricin 7: a novel bacteriocin produced by Bacillus thuringiensis BMG1.7, a new strain isolated from soil. Lett. Appl. Microbiol. 32(4): 243-7.

10. Collins, L.V., Kristian, S.A., Weidenmaier, C., Faigle, M., Van Kessel, K.P., Van Strijp, J.A., Götz, F., Neumeister, B. and Peschel, A. (2002). Staphylococcus aureus strains lacking D-alanine modifications of teichoic acids are highly susceptible to human neutrophil killing and are virulence attenuated in mice. J. Infect. Dis. 186(2): 214-9.

11. De Leo, F.R. and Chambers, H.F. (2009). Reemergence of antibiotic-resistant Staphylococcus aureus in the genomics era. J. Clin. Invest. 119(9): 2464-2474.

12. Fagerlund, A., Brillard, J., Furst, R., Guinebretiere, M.H. and Granum, P.E. (2007). Toxin production in a rare and genetically remote cluster of strains of the Bacillus cereus group. BMC Microbiol. 7: 43.

13. Garcia-Olmedo, F., Molina, A., Alamillo, J.M. and Rodriguez-Palenzuela, P. (1998). Plant defense peptides. Biopolymers (Peptide Science). 47: 479-491.

14. Guinebretiere, M.H., Auger, S., Galleron, N., Contzen, M., De Sarrau, B., De Buyser, M.L., Lamberet, G., Fagerlund, A., Granum, P.E., Lereclus, D., De Vos, P., Nguyen-The, C. and Sorokin, A. (2012). Bacillus cytotoxicus sp. nov. is a new thermotolerant species of the Bacillus cereus group occasionally associated with food poisoning. Int. J Syst. Evol. Microbiol. (Online) published.

15. Hammami, R., Ben Hamida, J., Vergoten, G. and Fliss, I. (2009a). PhytAMP: a database dedicated to antimicrobial plant peptides. Nucleic Acids Res. 37: 963-968.

16. Hammami, R., Ben Hamida, J., Vergoten, G., Lacroix, J.M., Solomianny, M.C., Neffati, M. and Fliss, I. (2009b). A new antimicrobial peptide isolated from Oudneya africana seeds. Microbiol. Immunol. 53(12): 658-66.

17. Hammami, R., Zouhir, A., Ben Hamida, J., Neffati, M., Vergoten, G., Naghmouchi, K. and Fliss, I. (2009c). Antimicrobial peptides of aqueous extracts from three medicinal plants growing wild in arid regions of Tunisia. Pharm. Biol. 47(5): 452-457.

18. Hancock, R.E.W. (2001). Cationic peptides: effectors in innate immunity and novel antimicrobials. Lancet Infect. Dis. 1: 156-164.

19. Hilliard, N.J., Schelonka, R.L. and Waites, K.B. (2003). Bacillus cereus bacteremia in a preterm neonate. J. Clin. Microbiol. 41: $3441-3444$.

20. Holmes, A., Ganner, M., McGuane, S., Pitt, T.L., Cookson, B.D. and Kearns, A.M. (2005). Staphylococcus aureus isolates carrying PantonValentine Leucocidin genes in England and Wales: frequency, characterization, and association with clinical disease. J. Clin. Microbiol. 43(5): 2384-2390.

21. Idris, U.E., Adam, S.E. and Tartour, G. (1982). An anthelmintic efficacy of Artemisia herba-alba against Haemonchus contortus infection in goat. National Institute of Animal Health 22(3): 138-143.

22. Jha, S., Tank, H.G., Prasad, B.D. and Chattoo, B.B. (2009). Expression of Dm-AMP1 in rice confers resistance to Magnaporthe oryzae and Rhizoctonia solani. Trans. Res. 18: 59-69.

23. Kluytmans, J., van Belkum, A. and Verbrugh, H. (1997). Nasal carriage of Staphylococcus aureus: epidemiology, underlying mechanisms, and associated risks. Clin. Microbiol. Rev. 10(3): 505-520.

24. Kovacs, M., Halfmann, A., Fedtke, I., Heintz, M., Peschel, A., Vollmer, W., Hakenbeck, R. and Bruckner, R. (2006). A functional dlt operon, encoding proteins required for incorporation of $\mathrm{D}$-alanine in teichoic acids in gram positive bacteria, confers resistance to cationic antimicrobial peptides in Streptococcus pneumoniae. J. Bacteriol. 188: 5797-5805.

25. Laemmli, U.K. (1970). Cleavage of structural proteins during the assembly of the head of bacteriophage T4. Nature. 227: 680-685.

26. Lay, F.T. and Anderson, M.A. (2005). Defensins-components of the innate immune system in plants. Curr. Protein Pept. Sci. 6(1): 85-101.

27. Liu, Y., Luo, J., Xu, C., Ren, F., Peng, C., Wu, G. and Zhao, J. (2000). Purification, characterization, and molecular cloning of the gene of a seed-specific antimicrobial protein from pokeweed. Plant Physiol. 122(4): 1015-1024.

28. Lopez-Solanilla, E., Gonzalez-Zorn, B., Novella, S., Vazquez-Boland, J.A. and Rodriguez-Palenzuela, P. (2003). Susceptibility of Listeria monocytogenes to antimicrobial peptides. FEMS Microbiol. Lett. 226: 101-105.

29. Lund, T., De Buyser, M.L. and Granum, P.E. (2000). A new cytotoxin from Bacillus cereus that may cause necrotic enteritis. Mol. Microbiol. 2: 254-261.

30. Mandal, S.M., Dey, S., Mandal, M., Sarkar, S., Maria-Neto, S. and Franco, O.L. (2009). Identification and structural insights of three novel antimicrobial peptides isolated from green coconut water. Peptides. 30(4): 633-637.

31. Marcus, J.P., Green, J.L., Goulter, K.C. and Manners, J.M. (1999). A family of antimicrobial peptides is produced by processing of a $7 \mathrm{~S}$ globulin protein in Macadamia integrifolia kernels. Plant J. 19(6): 699-710.

32. Martins, J. C., Maes, D., Loris, R., Pepermans, H.A., Wyns, L., Willem, R. and Verheyden, P. (1996). H NMR study of the solution structure of Ac-AMP2, a sugar binding antimicrobial protein isolated from Amaranthus caudatus. J. Mol. Biol. 258(2): 322-333.

33. Messaoudene, D., Belguendouz, H., Ahmedi, M.L., Benabdekader, T., Otmani, F., Terahi, M., Youinou, P. and Touil-Boukoffa, C. (2011). Ex vivo effects of flavonoïds extracted from Artemisia herba alba on cytokines and nitric oxide production in Algerian patients with Adamantiades-Behçet's disease. J. Inflammation (London, U. K.). 21: 8-35.

34. Miller, J.M., Hair, J.G., Hebert, M., Hebert, L., Roberts, F.J.Jr. and Weyant, R.S. (1997). Fulminating bacteremia and pneumonia due to Bacillus cereus. J. Clin. Microbiol. 35(2): 504-7.

35. Mills, S., Stanton, C., Hill, C. and Ross, R.P. (2011). New developments and applications of bacteriocins and peptides in foods. Annu. Rev. Food Sci. Technol. 2: 299-329.

36. Muramoto, N., Tanaka, T., Shimamura, T., Mitsukawa, N., Hori, E., Koda, K., Otani, M., Hirai, M., Nakamura, K. and Imaeda, T. (2012). Transgenic sweet potato expressing thionin from barley gives resistance to black rot disease caused by Ceratocystis fimbriata in leaves and storage roots. Plant Cell Rep. 31(6): 987-97.

37. Neerman, M.F. (2003). Sesquiterpene lactones: a diverse class of compounds found in essential oils possessing antibacterial and antifungal properties. Int. J. Aromather. 13: 114-120.

38. Odani, S., Koide, T., Ono, T., Seto, Y. and Tanaka, T. (1987). Soybean hydrophobic protein. Isolation, partial characterization and the complete primary structure. Eur. J. Biochem. 162(3): 485-91.

39. Perez, C., Paul, M. and Bazerque, P. (1990). Antibiotic assay by agar-well diffusion method. Acta Biol. Med. Exp. 15: 113-115. 
Fedhila et al., Afr J Tradit Complement Altern Med. (2015) 12(1):68-75

http://dx.doi.org/10.4314/ajtcam.v12i1.10

40. Saleh, N.A.M., El-Negoumy, S.I., Abd-All, M.F., Abou-Zaid, M.M., Dellamonica, G. and Chopin, J. (1985). Flavonoid glycosides of Artemisia monosperma and A. herba alba. Phytochemistry. 24: 201-203.

41. Som, A., Vemparala, S., Ivanov, I. and Tew, G.N. (2008). Synthetic mimics of antimicrobial peptides. Biopolymers. 90(2): 83-93.

42. Stenfors Arnesen, L.P., Fagerlund, A. and Granum, P.E. (2008). From soil to gut: Bacillus cereus and its food poisoning toxins. FEMS Microbiol. Rev. 32(4): 579-606.

43. Stotz, H.U., Thomson, J.G. and Wang, Y. (2009). Plant defensins: defense, development and application. Plant Signaling Behav. 4(11): $1010-2$.

44. Tossi, A., Sandri, L. and Giangaspero, A. (2000). Amphipathic, alpha-helical antimicrobial peptides. Biopolymers. 55: 4-30.

45. Van Den Bergh, K.P.B., Proost, P., Van Damme, J., Coosemans, J., Van Damme, E.J.M. and Peumans, W.J. (2002). Five disulfide bridges stabilize a hevein-type antimicrobial peptide from the bark of spindle tree (Euonymus europaeus L.). FEBS Lett. 530(1-3): 181-185.

46. Vázquez-Boland, J.A., Kuhn, M., Berche, P., Chakraborty, T., Domínguez-Bernal, G., Goebel, W., González-Zorn, B., Wehland, J. and Kreft, J. (2001). Listeria pathogenesis and molecular virulence determinants. Clin. Microbiol. Rev. 14(3): 584-640.

47. Wertheim, H.F., Melles, D.C., Vos, M.C., van Leeuwen, W., van Belkum, A., Verbrugh, H.A. and Nouwen, J. L. (2005). The role of nasal carriage in Staphylococcus aureus infections. Lancet Infect. Diss. 5(12): 751-762.

48. Yeung, A.T., Gellatly, S.L. and Hancock, R.E. (2011). Multifunctional cationic host defence peptides and their clinical applications. Cell. Mol. Life Sci. 68(13), 2161-76.

49. Zainal, Z., Marouf, E., Ismail, I. and Fei, C.K. (2009). Expression of the Capsicuum annuum (Chili) defensin gene in transgenic tomatoes confers enhanced resistance to fungal pathogens. Am. J. Plant Physiol. 4: 70-9. 